\title{
PDPGR \\ (PROGRAM DAERAH PEMBERDAYAAN GOTONG GOYONG) SEBAGAI INOVASI DALAM PENANGANAN PERCEPATAN REHABILITASI DAN REKONSTRUKSI PASCA GEMPA BUMI DI KABUPATEN SUMBAWA BARAT
}

\author{
Eddy Oswaronto ${ }^{1}$, Muhammad Saleh ${ }^{2^{\star}}$, Harjito ${ }^{3^{\star}}$ \\ ${ }^{123}$ Sekolah Pascasarjana Universitas Teknologi Sumbawa \\ *Corresponding Autor Email: muhammad.saleh@uts.ac.id, harjito@uts.ac.id
}

\begin{abstract}
Diterima :
Bulan September
2020
Abstrak

Penelitian ini bertujuan untuk mengetahui peran dan indikator keberhasilan PDPGR sebagai inovasi penanganan percepatan rehabilitasi dan rekonstruksi pasca gempa bumi di kabupaten Sumbawa Barat. Penelitian ini menggunakan pendekatan kualitatif. Teknik pengambilan data menggunakan observasi, wawancara, dan dokumentasi berupa peraturan dan kebijakan pemerintah kabupaten Sumbawa Barat terkait PDPGR. Informan dipilih dengan purposive sampling. Informan yang dipilih berjumlah 7 orang yang merupakan tim pengarah tingkat kabupaten, agen PDPGR, tokoh adat, tokoh

Diterbitkan :

Bulan Oktober 2020 agama, dan tokoh masyarakat. Data yang diperoleh dianalisis menggunakan tiga jalur yakni reduksi, penyajian data, dan penarikan kesimpulan yang dilakukan pada saat pengumpulan data berlangsung. Keabsahan data diuji menggunakan teknik triangulasi sumber. Hasil penelitian menunjukkan bahwa peran PDPGR sebagai penanganan percepatan rehabilitasi dan rekonstruksi pasca gempa antara lain; 1) Mempermudah dan

Keyword : PDPGR, Inovasi, Percepatan, Rehabilitasi, dan Rekonstruksi mempercepat pembentukan pokmas yang merupakan aturan dasar dalam proses rehabilitasi dan rekonstruksi pasca bencana. 2) Membantu proses pendataan masyarakat terdampak gempa secara cepat dan meyeluruh. Hal ini disebabkan adanya agen PDPGR yang terstruktur dan massif sampai tingkat blok yang tergabung dalam Pokmas Plus. 3) Membantu mempercepat proses admistrasi seperti pembuatan RAB, pencairan dana, pengurusan ke BPBD, dan pembuatan LPJ. Hal ini disebabkan agen PDPGR memiliki pengalaman terkait dengan program rehab rumah selama 2 tahun terakhir. 4) Memberikan ruang bagi masyarakat untuk ikut berpartisipasi aktif dalam mempercepat proses rehabilitasi dan rekonstruksi. Indikator keberhasilan PDPGR dalam mempercepat proses rehabilitasi dan rekonstruksi antara lain waktu pengerjaan yang lebih cepat daripada waktu yang diberikan BNPB serta kuantitas pekerjaan yang telah diselesaikan. Dari data diperoleh bahwa lebih dari 95\% rumah masyarakat terdampak gempa sudah terselesaikan dengan cepat baik untuk kategori Rusak Ringan (RR), Rusak Sedang (RS), dan Rusak Berat (RB).
\end{abstract}

\section{PENDAHULUAN}

Letak geografis Indonesia yang merupakan pertemuan beberapa lempeng benua menyebabkan Indonesia sangat rentan dengan bencana alam berupa gempa bumi dan tsunami. Bencana alam gempa bumi dan tsunami tidak hanya banyak memakan korban jiwa, namun juga merusak pemukiman, kantor pemerintahan, serta sarana prasarana ibadah dan sosial. Keadaan ini telah mendorong bangsa Indonesia untuk mengeluarkan Undang-Undang Nomor 24 Tahun 2007 tentang Penanggulangan Bencana. Untuk merealisasikan Undang-Undang tersebut, pada tahun 2008 telah diterbitkan Peraturan Pemerintah Nomor 21 tentang Penyelenggaraan Penanggulangan Bencana, Peraturan Pemerintah Nomor 22 tentang Pendanaan dan Pengelolaan Bencana, Peraturan Pemerintah
Nomor 23 tentang Peranserta Lembaga Internasional dan Lembaga Asing Nonpemerintah dalam Penanggulangan Bencana.

Keberhasilan bangsa Indonesia dalam menangani bencana bukan saja terletak pada ketersediaan perangkat Undang-Undang dan Peraturan Pemerintah yang terkait dengan kebencanaan, tetapi juga implementasi perangkat kebijakan tersebut di lapangan. Di hadapan perubahan politik, ekonomi, sosial dan budaya bangsa Indonesia serta perubahan global yang sangat cepat, bukan tidak mungkin implementasi Undang-Undang dan Peraturan Pemerintah Penanggulangan Bencana mengalami hambatan. Sebagai contoh, kebijakan otonomi daerah yang dimaksudkan untuk memberdayakan pemerintah daerah dan mendekatkan serta mengoptimalkan 
pelayanan dasar kepada masyarakat ternyata tidak dengan sendirinya meningkatkan kemampuan daerah menangani bencana. Kebijakan otonomi daerah sering dipahami terbatas sebagai keleluasaan untuk memanfaatkan sumberdaya tanpa dibarengi kesadaran untuk mengelolanya secara bertanggungjawab. Penggeseran wewenang dari pusat ke daerah seringkali tidak diiringi dengan pengalihan tanggung jawab pelayanan dan perlindungan kepada masyarakat. Akibatnya, pada saat bencana terjadi tanggapan daerah cenderung lambat dan seringkali tergantung pada pusat. Keadaan ini menjadi semakin rumit apabila bencana tersebut meliputi lebih dari satu daerah. Di lain pihak, pada saat terjadi bencana, kurangnya koordinasi antar tataran pemerintahan menghambat pelaksanaan tanggapan yang cepat, optimal dan efektif.

Berdasarkan uraian di atas, setiap daerah sepatutnya memiliki inovasi tersendiri untuk mengatasi kesenjangan yang terjadi. Menurut Gopalakrishan dan Damanpur dalam Noor (2017) mengungkapkan, inovasi pada dasarnya menunjukkan pada sesuatu yang baru, apakah berbentuk gagasan-gagasan baru, produk, metode atau bentuk pelayanan. Pemerintah kabupaten Sumbawa Barat juga mengalami permasalahan yang sama, dan terlebih lagi berhubungan dengan permasalahan tata kelola dan pelayanan publik yang menjadi latar belakang pengembangan suatu inovasi dalam tata kelola dan pelayanan publik. Untuk mengatasi permasalahan tersebut, pemerintah Kabupaten Sumbawa Barat mengembangkan Program Daerah Pemberdayaan Gotong Royong (PDPGR).

PDPGR merupakan aksi daerah, gerakan aparatur dan masyarakat Kabupaten Sumbawa Barat dengan semangat kerja "Ikhlas, Jujur dan Sungguh-sungguh (IJS)". Untuk merealisasikan gotong royong sebagai sarana partisipasi dan integrasi sosial masyarakat dalam pembangunan, telah tersedia pedoman pelaksanaan pemberdayaan gotong royong yang menjamin efisiensi (daya guna), efektivitas (hasil guna), produktivitas dan keberlanjutan pemberdayaan gotong royong.

Sebelumnya telah dilakukan penelitian oleh Abdulkadir (2017) tentang evaluasi implementasi PDPGR di Daerah Otonom Baru (DOB) di kabupaten Sumbawa Barat. Dengan pendekatan kualitatip, maka pada dimensi Konteks, Masukan dan Proses secara keseluruhan sudah memenuhi kriteria. Beberapa indikator pada dimensi Produk, yang digunakan dalam studi ini adalah sasaran penerima, partisipasi masyarakat, dan manfaat yang diterima masyarakat. Berdasarkan hasil pengamatan di lapangan dan pengolahan data diperoleh bahwa pertama; untuk indikator sasaran penerima, kelompok masyarakat desa yang paling mendapatkan keuntungan dari PDPGR ini adalah masyarakat miskin pada sektor; Usaha Mikro, Pertanian, Peternakan, serta Perikanan \& Kelautan. Kedua; Indikator partisipasi masyarakat, diperoleh kategori dalam partisipasi sedang. Ketiga; untuk indikator manfaat yang diterima, diperoleh bahwa manfaat bidang keterampilan, pengetahuan, kesehatan, dan pendapatan yang diterima masyarakat desa masih dikategorikan dalam kategori kenaikan sedang. Namun pada akhirnya dengan otoritas penuh para Agen mampu memberdayakan masyarakat menurunkan angka kemiskinan secara signifikan.

Berdasarkan hasil penelitian di atas dapat meyakinkan bahwa keberadaan pemberdayaan gotong royong sebagai suatu program yang sangat bermanfaat dalam mempercepat pemenuhan kebutuhan dasar masyarakat (basic needs) di Kabupaten Sumbawa Barat. Sehingga PDPGR dipandang sangat layak untuk dikembangkan dan direplikasikan menjadi "Inovasi Pembangunan dan Tata Kelola Pemerintahan Daerah" dalam memberikan pelayanan publik di zaman modern saat ini.

Bencana gempa bumi yang melanda beberapa daerah dai NTB pada tahun 2018 termasuk di daerah kabupaten Sumbawa Barat menyebabkan pemerintah mengeluarkan kebijakan penerapan skema PDPGR dalam rangka mempercepat proses rehabilitasi dan rekonstruksi pasca gempa bumi. Hal inilah yang dikaji oleh peneliti terkait dengan peran dan indikator keberhasilan PDPGR sebagai inovasi penanganan percepatan rehabilitasi dan rekonstruksi pasca gempa bumi di Kabupaten Sumbawa Barat.

Fokus penelitian ini yaitu untuk mengetahui peran dan indikator keberhasilan PDPGR sebagai inovasi penanganan percepatan rehabilitasi dan rerekonstruksi pasca gempa bumi Di Kabupaten Sumbawa Barat.

\section{LANDASAN TEORI \\ Program Daerah Pemberdayaan Gotong Royong (PDPGR)}

Inovasi adalah suatu gagasan, praktek, atau benda yang dianggap/dirasa baru oleh individu atau kelompok masyarakat. Inovasi merupakan bagian integral bagi suatu organisasi, karena bukan hanya digunakan sebagai motor penggerak keberlangsungan organisasi, melainkan juga sebagai bentuk kemampanan dalam berkompetisi dengan organisasi lain. United Nations Departement of Economic And Social Affairs (2006) memberikan analisis tentang inovasi sebagai bagian dari revitalisasi administrasi publik, adanya inovasi dan eksperimen di pemerintah pusat dan daerah khususnya di bidang pelayanan dan pada saat ini berlangsung di berbagai penjuru dunia sebagai bagian dari upaya pemerintah untuk merevitalisasi administrasi publik. 
Menurut Gopalakrishan dan Damanpur dalam Noor (2017) mengungkapkan, inovasi pada dasarnya menunjukkan pada sesuatu yang baru, apakah berbentuk gagasangagasan baru, produk, metode atau bentuk pelayanan. Sedangkan inovasi menurut Rogers dalam Noor (2007), inovasi tidak hanya berurusan dengan pengetahuan baru dan cara-cara baru, tetapi juga dengan nilai-nilai karena harus bisa membawa hasil yang lebih baik, jadi selain melibatkan Iptek baru, tetapi juga melibatkan cara pandang dan perubahan sosial. Selanjutnya menurut Albury menyatakan secara sederhana bahwa inovasi sebagai new ideas that work. Ini berarti bahwa inovasi berhubungan erat dengan ide-ide baru yang bermanfaat. Inovasi dengan sifat kebaruannya harus mempunyai nilai manfaat. Sifat baru dari inovasi tidak akan berarti apa-apa apabila tidak diikuti dengan nilai kemanfaatan dari kehadirannya.

Inovasi merupakan cara baru untuk menggantikan cara lama dalam mengerjakan atau memproduksi sesuatu. Dalam penelitian ini, inovasi yang dimaksud yakni Prorgam Daerah Pemberdayaan Gotong Royong (PDPGR). Kegiatan pemberdayaan gotong royong pada Program Daerah Pemberdayaan Gotong Royong (PDPGR) di Kabupaten Sumbawa Barat diselengarakan oleh Kelembagaan Pengelola PDPGR melalui "pendekatan sistem (system approach)" dengan menerapkan fungsi-fungsi manajemen berdasarkan "pendekatan hubungan fungsional yang sistematis". Adanya kombinasi dari kedua pendekatan itulah yang membedakan pengelolaan kegiatan pemberdayaan gotong royong sebagai "inovasi pembangunan dan tata kelola pemerintahan daerah" (sebagai inovasi baru dan/atau penyempurnaan) dibandingkan dengan pengelolaan kegiatan gotong royong dari model/program sebelumnya.

Pemerintah Kabupaten Sumbawa Barat telah menetapkan Pemberdayaan Gotong Royong sebagai program unggulan daerah melalui Peraturan Daerah Kabupaten Sumbawa Barat Nomor 3 Tahun 2016 tentang Program Daerah Pemberdayaan Gotong Royong (PDPGR) di Kabupaten Sumbawa Barat. PDPGR adalah penyediaan ruang dan penegasan arah penguatan gotong royong sebagai suatu nilai dan cara mencapai tujuan yang dilaksanakan secara sukarela, bersama-sama dan tolong menolong dengan dilandasi semangat Ikhlas, Jujur, dan Sungguh-sungguh (IJS) dalam mewujudkan pembangunan, pemberdayaan masyarakat dan perluasan kesempatan kerja secara efektif dan efisien untuk percepatan pengentasan kemiskinan.

Pemberdayaan (empowerment) adalah proses perbaikan pola fikir (kognitive), sikap mental (afective) dan pola tindak (psicomotoric) sumberdaya manusia/masyarakat, baik secara perorangan maupun berkelompok/lembaga, dalam melaksanakan berbagai aktivitas kehidupan guna peningkatan kesejahteraan sosial ekonominya. Menurut Pangabean (2015) dalam kajiannya tentang pemberdayaan masyarakat dalam pembangunan menyimpulkan bahwa dengan dilakukannya pemberdyaaan masyarakat dalam pembangunan maka dapat memberikan arahan pencapaian sasaran dan tujuan pembangunan masyarakat secara optimal dan berkelanjutan.

Gotong royong adalah kegiatan kerjasama masyarakat, baik secara orang perorangan maupun berkelompok dalam berbagai bidang pembangunan yang diarahkan pada penguatan persatuan dan kesatuan, serta peran aktif masyarakat dalam rangka peningkatan kesejahteraan sosial ekonomi masyarakat dan pengembangan sosial ekonomi wilayah. Eksistensi gotong royong yang berakar dari budaya bangsa ini harus dibangkitkan lagi. Terlebih dari dalam konteks pembangunan yang menuntut peran serta masyarakat sebagai subyek dan obyek pembangunan. Menurut Effendi (2013) dalam kajiannya tentang budaya gotong royong masyarakat dalam perubahan sosial saat ini menyimpulkan bahwa gotong royong telah tumbuh dan berkembang dalam masyarakat kita sejak lama. Dalam budaya gotong royong melekat nilai-nilai substansi modal sosial. Sebagai modal sosial, gotong royong dapat dijadikan rujukan dan pegangan dalam mencapai kemajuan suatu bangsa. Itu artinya bila masyarakat masih memegang teguh prinsip gotong royong sebagai modal sosial maka lebih mudah dalam mencapai kemajuan bersama. Sebaliknya, bila nilai-nilai gotong royong yang terkandung dalam modal sosial tidak lagi menjadi pegangan dan rujukan dalam masyarakat dan komunitas bisa jadi akan mengalami kesulitan karena energi sosial bisa terbuang sia-sia dan berpotensi menghalangi mencapai tujuan kemajuan bersama. Bahkan bisa memicu munculnya kekacauan sosial.

Pemberdayaan Gotong Royong secara umum dilakukan melalui 3 jenis gotong royong yaitu: Gotong Royong Mandiri/Swadaya, Gotong Royong Stimulan, dan Gotong Royong Padat Karya. Pertama, Gotong Royong Mandiri adalah gotong royong yang kegiatannya direncanakan secara sederhana, dibiayai dan dilaksanakan bersama oleh masyarakat secara swadaya murni atau partisipasi sukarela dalam rangka mencapai tujuan dan kepentingan bersama anggota masyarakat. Kedua, Gotong Royong Stimulan adalah gotong royong yang kegiatannya direncanakan dan dilaksanakan sendiri oleh masyarakat dengan dukungan pemberdayaan dan/atau biaya pendampingan dari Pemerintah Daerah atau Pemerintah Desa atau Dunia Usaha/Perusahaan melalui dana Corporate Social Responsibility/CSR dan atau sumber lainnya yang sah. Ketiga, Gotong Royong Padat Karya 
adalah gotong royong yang kegiatannya direncanakan dan dibiayai oleh Pemerintah Daerah melalui APBD atau Pemerintah Desa melalui APBDes atau Perusahaan/Sumber Lainnya yang Sah melalui dana Corporate Social Responsibility (CSR) atau Sumber lainnya yang sah, yang pelaksanaan kegiatan diserahkan kepada masyarakat.

\section{Rehabilitasi dan Rekonstruksi Pasca Gempa}

Rehabilitasi adalah Perbaikan dan Pemulihan semua aspek layanan publik/ masyarakat sampai tingkat memadai pada wilayah pascabencana dengan sasaran utama Normalisasi/ berjalannya secara wajar berbagai aspek pemerintahan dan kehidupan masyarakat seperti pada kondisi sebelum terjadinya bencana.

Rekonstruksi adalah Pembangunan kembali semua prasarana dan sarana serta kelembagaan pada wilayah pasca bencana pemerintahan/ masyarakat dengan sasaran utama Tumbuh kembangnya kegiatan ekonomi, sosial dan budaya, tegaknya hukum dan ketertiban serta bangkitnya peran serta masyarakat dalam segala aspek kehidupan.

Berdasarkan dengan Undang-Undang No. 24 paa Tahun 2007 mengenai Penanggulangan Bencana, yang mana arti mitigasi ini ialah suatu rangkaian dari bentuk upaya yang dilakukan udah dapat meminimalisir dari terjadinya risiko dan juga dampak bencana, itu baik dengan melalui pembangunan infrastruktur maupun juga dengan memberikan kesadaran dan juga kemampuan untuk dapat menghadapi bencana.

Menurut UU Nomor 24 Tahun 2007, manajemen bencana adalah suatu proses dinamis, berlanjut dan terpadu untuk meningkatkan kualitas langkah-langkah yang berhubungan dengan observasi dan analisis bencana serta pencegahan, mitigasi, kesiapsiagaan, peringatan dini, penanganan darurat, rehabilitasi dan rekonstruksi bencana.

Menurut Peraturan Kepala Badan Penanggulangan Bencana Nomor 11 Tahun 2008 tentang pedoman rehabilitasi dan rekonstruksi pasca bencana, dijelaskan bahwa rehabilitasi adalah perbaikan dan pemulihan semua aspek pelayanan publik atau masyarakat sampai tingkat yang memadai pada wilayah pasca bencana dengan sasaran utama untuk normalisasi atau berjalannya secara wajar semua aspek pemerintahan dan kehidupan masyarakat pada wilayah pascabencana. Rehabilitasi dilakukan melalui kegiatan (a) perbaikan lingkungan daerah bencana; (b) perbaikan prasarana dan sarana umum; (c) pemberian bantuan perbaikan rumah masyarakat; (d) pemulihan sosial psikologis; (e) pelayanan kesehatan; (f) rekonsiliasi dan resolusi konflik; (g) pemulihan sosial ekonomi budaya; (h) pemulihan keamanan dan ketertiban; (i) pemulihan fungsi pemerintahan; dan (j) pemulihan fungsi pelayanan publik.

Kegiatan rehabilitasi harus memperhatikan pengaturan mengenai standar rekonstruksi bangunan, kondisi sosial, adat istiadat, budaya dan ekonomi. Pemberian bantuan perbaikan rumah masyarakat merupakan bantuan Pemerintah sebagai stimulan untuk membantu masyarakat memperbaiki rumahnya yang mengalami kerusakan akibat bencana untuk dapat dihuni kembali. Bantuan Pemerintah sebagaimana dimaksud dapat berupa bahan material, komponen rumah atau uang yang besarnya ditetapkan berdasarkan hasil verifikasi dan evaluasi tingkat kerusakan rumah yang dialami.

Bantuan pemerintah untuk perbaikan rumah masyarakat sebagaimana dimaksud diberikan dengan pola pemberdayaan masyarakat dengan memperhatikan karakter daerah dan budaya masyarakat, yang mekanisme pelaksanaannya ditetapkan melalui koordinasi BPBD. Tujuan pemberian bantuan perbaikan rumah masyarakat dimaksudkan untuk memperbaiki kondisi rumah masyarakat agar dapat mendukung kehidupan masyarakat, seperti komponen rumah, prasarana, dan sarana lingkungan perumahan yang memungkinkan berlangsungnya kehidupan sosial dan ekonomi yang memadai sesuai dengan standar pembangunan perumahan sebagaimana diatur dalam peraturan perundang-undangan.

Rekonstruksi adalah perumusan kebijakan dan usaha serta langkah-langkah nyata yang terencana baik, konsisten dan berkelanjutan untuk membangun kembali secara permanen semua prasarana, sarana dan sistem kelembagaan, baik di tingkat pemerintahan maupun masyarakat, dengan sasaran utama tumbuh berkembangnya kegiatan perekonomian, sosial dan budaya, tegaknya hukum dan ketertiban, dan bangkitnya peran dan partisipasi masyarakat sipil dalam segala aspek kehidupan bermasyarakat di wilayah pasca bencana.

Rekonstruksi fisik adalah tindakan untuk memulihkan kondisi fisik melalui pembangunan kembali secara permanen prasarana dan sarana permukiman, pemerintahan dan pelayanan masyarakat, prasarana dan sarana ekonomi (jaringan perhubungan, air bersih, sanitasi dan drainase, irigasi, listrik dan telekomunikasi ), prasarana dan sarana sosial yang rusak akibat bencana, agar kembali ke kondisi semula atau bahkan lebih baik dari kondisi sebelum bencana.

\section{METODE PENELITIAN}

Jenis penelitian ini adalah penelitian kualitatif. Penelitian kualitatif adalah suatu penelitian yang perlu dilakukan yang sesuai dengan masalah yang diteliti (Maleong, 2007). Menurut Sudrajat (2015), 
penelitian kualitatif adalah suatu prosedur yang menggunakan data deskriptif berupa kata-kata tertulis atau lisan dari orang-orang dan pelaku yang bisa diamati. Penelitian kualitatif cenderung berkembang dan banyak digunakan dalam ilmuilmu sosial yang berhubungan dengan perilaku sosial/manusia, dengan berbagai argumentasi tentunya.

Penelitian dilaksanakan dari bulan Agustus 2019 sampai dengan Januari 2020 bertempat di kantor Pemerintah Daerah KSB dan beberapa lokasi di wilayah KSB. Pemilihan sumber data dalam penelitian ini dengan cara purposive sampling yaitu informan yang dipilih harus mengetahui, memahami, bahkan termasuk dalam sistem kerja PDPGR. Informanyang akan dijadikan obyek untuk diwawancarai adalah beberapa pejabat di Pemerintahan Daerah Kabupaten Sumbawa Barat yaitu diantaranya adalah Bupati Sumbawa Barat, Wakil Bupati Sumbawa Barat, Sekda Sumbawa Barat dan Asisten 2 Sumbawa Barat, tokoh adat, tokoh agama, dan tokoh masyarakat.

Alasan pemilahan informan diatas adalah pejabat tersebut merupakan pejabat pembuat kebijakan publik di Pemerintahan Kabupaten Sumbawa Barat yang memiliki ide dan konsep terkait PDPGR, serta tokoh masyarakat, tokoh adat dan tokoh agama mewakili masyarakat secara umum dalam memberikan penilaian terhadap kebijakan Pemrintah Daerah terkait PDPGR.

Teknik pengumpulan data yang digunakan dalam penelitian ini adalah observasi , wawancara dan dokumentasi. Dalam penelitian ini digunakan metode interview bebas terpimpin yang merupakan kombinasi interview bebas dengan interview terpimpin, dimana pewawancara membawa pedoman yang hanya merupakan garis besar tentang hal-hal yang ditanyakan. Dokumentasi merupakan catatan peristiwa yang sudah berlalu. Dokumen bisa berbentuk tulisan, gambar, atau karya-karya monumental. Dalam penelitian ini diperoleh dokumen dalam bentuk tulisan berapa peraturan dan kebijakan pemerintah kabupaten Sumbawa Barat terkait PDPGR.

Keabsahan data dicek menggunakan teknik triangulasi sumber yang ditunjukkan dengan jumlah informan wawancara lebih dari satu informan. Keabsahan data juga dicek dengan mendiskusikan dengan pakar atau orang yang lebih ahli termasuk koreksi di bawah bimbingan dosen pembimbing. Dari diskusi ini diperoleh kritik dan masukan segala macam proses penelitian, sehingga terjadi interaksi yang dapat mendukung pelaksanaan penelitian dengan baik.

Analisis data yang digunakan adalah reduksi data (data reduction), penyajian data (data displays), dan penarikan kesimpulan/verifikasi ( conclusion drawing / veriffication). Analisis data dalam penelitian kualitatif, dilakukan pada saat pengumpulan data berlangsung dan setelah selesai pengumpulan data(Sugiyono, 2013).

\section{HASIL DAN PEMBAHASAN \\ Peran PDPGR Sebagai Inovasi Penanganan Percepatan Rehabilitasi dan Rekonstruksi Pasca Gempa Bumi Di Kabupaten Sumbawa Barat}

Bencana gempa bumi yang terjadi di daerah kabupaten Sumbawa Barat mengakibatkan banyak rusaknya fasilitas publik dan rumah tempat tinggal penduduk. Kondisi ini mengharuskan pemerintah untuk melaksanakan proses rehabilitasi dan rekonstruksi bangunan pasca gempa berdasarkan Undang-Undang Nomor 24 Tahun 2007 tentang Penanggulangan Bencana. Untuk merealisasikan Undang-Undang tersebut, pada tahun 2008 telah diterbitkan Peraturan Pemerintah Nomor 21 tentang Penyelenggaraan Penanggulangan Bencana, Peraturan Pemerintah Nomor 22 tentang Pendanaan dan Pengelolaan Bencana.

Menurut Perka PNPB Nomor 14 Tahun 2104 tentang petunjuk teknis tata cara pengajuan dan pengelolaan dana bantuan sosial pasca gempa dijelaskan bahwa penyelenggaraan rehabilitasi dan rekonstruksi merupakan bagian tak terpisahkan dalam perencanaan pembangunan, memerlukan aspek perencanaan dan pendanaan sesuai yang diatur peraturan perundang-undangan oleh Pemerintah baik dalam bentuk kebijakan perencanaan, pendanaan dan kebijakan pembangunan daerah. Secara teknis, pelaksanaan rehabilitasi dan rekonstruksi memerlukan dokumen perencanaan dalam bentuk rencana aksi atau proposal perencanaan lain yang disetarakan. Selaras dengan Pasal 5 Peraturan Pemerintah Nomor 22 Tahun 2008 tentang Pendanaan dan Pengelolaan Bantuan Bencana, Pemerintah menyediakan dana bantuan kepada daerah yang terkena bencana dalam bentuk dana bantuan sosial berpola hibah. Undang-Undang Nomor 10 Tahun 2010 tentang Anggaran Pendapatan dan Belanja Nasional (APBN) tahun 2011 menyatakan bahwa pengalokasian dana bantuan sosial berpola hibah ini berada di Badan Nasional Penanggulangan Bencana (BNPB).

Lebih lanjut dalam strategi yang dijelaskan dalam Perka PNPB nomor 14 Tahun 2011 disebutkan bahwa khusus untuk Bantuan Langsung Masyarakat (BLM) dilaksanakan melalui Kelompok Masyarakat (POKMAS) yang berbasis masyarakat. Aturan ini mengaharuskan pembentukan POKMAS sebagai syarat pencairan dana bantuan. Namun, pembentukan POKMAS ini menjadi masalah tersendiri karena memerlukan pendataan yang teliti dari masyarakat terdampak gempa, dimana pendataannya memerlukan waktu dan proses yang cukup memakan waktu. Sehingga tidak heran di beberapa daerah terdampak gempa 
banyak ditemukan permasalahan keterlambatan pembentukan pokmas dan tidak menyentuh semua masyarakat terdampak gempa.

Program Daerah Pemberdayaan Gotong Royong (PDPGR) merupakan program yang dicanangkan oleh Bupati dan Wakil Bupati kabupaten Sumbawa Barat sejak tahun 2016 melalui Peraturan Daerah Kabupaten Sumbawa Barat Nomor 3 Tahun 2016 tentang Program Daerah Pemberdayaan Gotong Royong (PDPGR) di Kabupaten Sumbawa Barat.Program Daerah Pemberdayaan Gotong Royong (PDPGR). PDPGR menekankan pada partisipasi aktif masyarakat sebagai subyek dan obyek dari pembangunan daerah dengan konsep IJS (Ikhlas, Jujur, dan Sungguh-sungguh). PDPGR memiliki fungsi dalam perencanaa, pembiayaan, pelaksanaan, pengendalian dan pengawasan, serta evaluasi dan pelaporan. Kelembagaan PDPGR sangat sistematis dan massif. Dimulai dari Tim Pengarah tingkat kabupaten sampe tim pada tingkat desa bahkan blok yang disebut Agen Pemberdayaan Gotong Royong. Agen Pemberdayaan terdiri atas Agen Pemberdayaan Tingkat Kecamatan 2 orang per kecamatan (ada 8 kecamatan), Agen Pemberdayaan Tingkat Desa/Kelurahan 2 orang per desa/kelurahan (ada 64 desa/kelurahan), dan Agen Pemberdayaan Tingkat Peliuk/Blok Wilayah 3 orang per peliuk/blok wilayah (ada 193 Peliuk).

Terdapatnya agen PGR sampai pada tingkat paling rendah memudahakan pemerintah kabupaten Sumbawa Barat dalam pembentukan POKMAS yang disebut sebagai POKMAS Plus. Pokmas Plus terdiri dari masyarakat terdampak gempa sebagai anggotanya dan agen PGR sebagai ketuanya. Karena daari tahun 2016 sudah terdata dan terkelompok dengan rapi, hal ini memudahkan dalam pendataan masyarakat terdampak gempa. Adanya POKMAS Plus memberikan percepatan dalam proses pendataan, pencairan, pelaksanaan, sampai dengan pelaporan. Berdsarkan hasil wawancara juga dijelaskan bahwa dengan adanya PDPGR skema-skema yang diberikan dalam pengelolaan dana bantuan berupa pokmas-pokmas dari pemerintah bisa kita sesuaikan. Justru keberadaan agen-agen ini yang menjadi pilar utama yang menentukan betapa cepatnya kita dibandingkan tempat lain. Agen PGR sebagai pokmas plus dibantu oleh agen penggerak di tingkat desa, agen pembina tingkat kecamatan, di tingkat kabupaten ada pembina dan pengarah. Sistem inilah yang membuat perbedaan signifikan penanganan gempa dengan kabupaten/kota lainnya. Bekerjanya sistem ini mulai dari pendataan, perencanaa, eksekusi, pembayaran, dan pelaporan .

Selain struktur PDPGR yang sistematis sampai ke tingkat peliuk, penanganan percepapatan rehabilitasi dan rekonstruksi pasca gempa juga dipengaruhi oleh pengalaman Sumbawa Barat dari tahun 2016 dengan kelompok masyarakat yang sudah ada bersama Agen Pemberdayaan Gotong Royong yang berjumlah 193 Peliuk. Pengalaman ini membuat kabupaten Sumbawa Barat tidak perlu "belajar" lagi dalam mengadaptasi penangangan pasca gempa bumi.

Selain 2 hal tersebut, perubahan sikap mental masyarakat yang semangat ikut berpasrtisipasi aktif tolong-menolong dalam rehabilitasi dan rekonstruksi sebagai perubahan mindset sebagai dampak PDPGR juga memberi peran penting dalam percepatan penanganan pasca gempa. Gotong royong adalah modal dari pembangunan. Di lapangan, agen PDPGR ini dibantu oleh Babinsa TNI, Babhinkamtibmas Polri, dan masyarakat. Tak hanya Agen Pemberdayaan Gotong Royong , anggota TNI dan Polri, pemerintah Daerah Aparatur Sipil Negara dalam mempercepat proses rehab rekon korban terdampak gempa. Dengan semangat kebersamaan, semua unsur bahu membahu membantu masyarakat untuk bangkit dari keterpurukan.

Menurut Effendi (2013) dalam kajiannya tentang budaya gotong royong masyarakat dalam perubahan sosial saat ini menyimpulkan bahwa gotong royong telah tumbuh dan berkembang dalam masyarakat kita sejak lama. Dalam budaya gotong royong melekat nilai-nilai substansi modal sosial. Sebagai modal sosial, gotong royong dapat dijadikan rujukan dan pegangan dalam mencapai kemajuan suatu bangsa. Itu artinya bila masyarakat masih memegang teguh prinsip gotong royong sebagai modal sosial maka lebih mudah dalam mencapai kemajuan bersama.

Dari pembahasan di atas dapat disimpulkan bahwa peran PDPGR sebagai inovasi penanganan percepatan rehabilitasi dan rekonstruksi pasca gempa di kabupaten Sumbawa Barat diepangaruhi oleh 3 hal yaitu :

1. Keberadaan agen pemberdayaan gotong royong memudahkan pemerintah dalam membentuk POKMAS Plus sehingga pendataan masyarakat terdampak gempa, pencairan, pelaksanaan, dan pelaporan menjadi lebih cepat dari waktu yang ditargetkan.(Fakta pada tanggal 15 Oktober 2018 KSB menjado Kabupaten pertama yang membentuk Pokmas dan dapat mencairkan dana rehab rekon tahap 1)

2. Adanya pengalaman PDPGR dari tahun 2016 memudahkan untuk mengadaptasi skemaskema yang diberikan oleh pemerintah pusat.

3. Adanya perubahan mindset masyarakatan untuk tolong-menolong dalam bentuk gotong royong dalam segala hal. 
Indikator Keberhasilan PDPGR Sebagai Inovasi Penanganan Percepatan Rehabilitasi dan Rekonstruksi Pasca Gempa Bumi Di Kabupaten Sumbawa Barat

Keberhasilan PDPGR sebagai inovasi penanganan percepatan rehabilitasi dan rekonstruksi pasca gempa di kabupaten Sumbawa Barat terlihat dari beberapa indikator yaitu waktu pengerjaan yang lebih cepat, kuantitas pekerjaan yang banyak dan cakupan yang luas, penggunaan dana yang efekif dan efisien, serta tidak terdapatnya protes/demonstrasi dari masyarakat terkait proses pengerjaan.

Waktu pengerjaan yang lebih cepat dari target merupakan indikator keberhasilan PDPGR mempercepat rehabilitasi dan rekonstruksi. Hal ini terlihat dari data yang disampaikan oleh Bupati kabupaten Sumbawa Barat. Menurut hasil wawancara dijelaskan bahwa rehabilitasi dan rekonstruksi menggunakan mekanisme PDPGR ini sangat efektif karena didasari jiwa IJS (Ikhlas, Jujur, dan Sungguh-sungguh), sehingga tidak ada keraguan terhadap mekanisme ini. Dari hasil evaluasi dengan membandingkan dengan nilai uang, selalu saja fisik itu nilainya lebih tinggi dari uang yang diterima. Bahkan pada saat uang yang kita dapatkan mencapai $47 \%$, fisik kita sudah mencapai $85 \%$. Ini membuktikan ada partisipasi yang aktif yang terjadi pada mekanisme PDPGR.

Waktu pengerjaan yang relatif cepat ini terjadi karena mekanisme PDPGR sudah sangat sistematis. Pembentukan POKMAS Plus dari agen PGR dapat mempercepat proses pendataan, pencairan, pengerjaan, dan pelaporan. Terlebih lagi dengan pengalaman PGPGR dari tahun 2016 memudahkan pemerintah dalam mengadaptasi skema-skema yang diberikan oleh pemerintah pusat.

Indikator kedua keberhasilan PDPGR mempercepat rehabilitasi dan rekonstruksi adalah kuantitas pekerjaan dan cakupan yang luas. Terdapatnya agen PGR di 193 peliuk mampu mendata secara keseluruhan sehingga dapat diselesaikan sesuai dengan rencana. Data jumlah rumah terdampak dan telah direhabilitasi dan direkonstruksi di KSB totalnya sebanyak 18.430 unit. Rumah kategori Rusak Berat sebanyak 1.286 unit dan telah selesai dibangun 95 persen lebih. Rusak Sedang sebanyak 3.835 dan telah tuntas dikerjakan seluruhnya. Sementara Rusak Ringan sebanyak 13.309 unit dan telah tuntas dikerjakan sebanyak 98,49 persen.

Menurut Peraturan Kepala Badan Penanggulangan Bencana Nomor 11 Tahun 2008 tentang pedoman rehabilitasi dan rekonstruksi pasca bencana menjelaskan indikator pencapaian rehabilitasi rumah masyarakat pasca bencana sebagai berikut:
1. Bantuan diterimakan ke masyarakat dan dimanfaatkan sebagai sumberdaya pembangunan/rehabilitasi.

Bantuan diterima oleh seluruh masyarakat terdampak gempa di kabupaten Sumbawa Barat karena pendataan yang cepat dan merata yang dilakukan oleh agen PDPGR sampe tingkat peliuk. Agen PDPGR dibantu oleh Babinsa TNI, Babhinkamtibmas Polri, Kepala Dusun dan Kepala Desa/Lurah. Selanjutnya data tersebut diverifikasi kembali oleh tim ditingkat pemerintah daerah. Dengan adanya kerjasama dalam konsep gotong royong ini mampu mempercepat pendataan yang valid untuk masyarakat terdampak gempa.

2. Adanya share dari masyarakat, baik berupa dana, tenaga, material, untuk pelaksanaan rehabilitasi rumah.

PDPGR menekankan pada gotong royong dan terbentuknya swadaya masyarakat. Bersdasarkan temuan di lapangan, bila dana stimulan tidak cukup maka kelompok masyarakat akan melakukan swadaya untuk membantu masyarakat lainnya.

3. Perbaikan/rehabilitasi rumah terlaksana Indikator ini ditunjukkan dengan prosentase penyelesaian proses rehabilitasi dan rekonstruksi pasca gempa diatas 90\% baik untuk rumah kategori Rusak Berat (RB), Rusak Sedang (RS), maupun Rusak Ringan (RR).

4. Rumah kembali layak huni, memenuhi kondisi minimal Rumah Sehat Sederhana

5. Masyarakat korban kembali bermukim.

6. Tersalurkannya dana bantuan berupa stimulan

7. Diterimanya dana bantuan oleh masyarakat korban yang membutuhkan

8. Terdistribusikannya material dan komponen bangunan sesuai kebutuhan korban

9. Terdistribusikannya peralatan pembangunan untuk tindak perbaikan rumah

10. Hadirnya SDM sesuai kebutuhan penyelenggaraan perbaikan

11. Fisik bangunan dapat memberikan naungan/shelter dan jaminan perlindungan (kokoh), sesuai dengan standard teknis bangunan

Indikator pencapaian rehabilitasi dan rekonstruksi yang diberikan oleh PNPB dapat dicapai dengan lebih cepat menggunakan mekanisme PDPGR. Indikator keberhasilan PDPGR lainnya adalah tidak terdapatnya protes/demonstrasi atas proses yang terjadi, tidak sepeti di daerah lain. Protes-protes seringkali terjadi karena pendataan yang tidak akurat dan tidak tepat sasaran, proses yang lama, dan bahkan ketidak jujuran oknum POKMAS. Dengan skema PDPGR, pendataan yang dilakukan merat dan dalam waktu yang relatif cepat serta PDPGR 
berlandaskan jiwa IJS (Ikhlas, Jujur, dan Sunguhsungguh).

\section{PENUTUP}

\section{Kesimpulan}

Berdasarkan hasil penelitian dan pembahasan dapat diambil kesimpulan sebagai berikut :

1. PDPGR (Program Daerah Pemberdayaan Gotong Royong ) sebagai inovasi penanganan percepatan rehabilitasi dan rekonstruksi pasca gempa di kabupaten Sumbawa Barat dapat ditinjau dari beberapa hal. Peran Agen Pemberdayaan Gotong Royong sangat penting dalam percepatan proses awal pembentukan POKMAS Plus sehingga mempercepat proses pendataan secara menyeluruh, pencairan, pelaksanaan, dan pelaporan. Adanya pengalaman PDPGR dari tahun 2016 memudahkan untuk mengadaptasi skemaskema yang diberikan oleh pemerintah pusat. Adanya perubahan mindset masyarakatan untuk tolong-menolong dalam bentuk gotong royong dalam segala hal. Dengan prinsip Gotong Royong yang telah disebutkan diatas yang melandasi semua kegiatan yang dilakukan PDPGR sebagai Pokmas Plus sehingga membantu percepatan kegiatan rehab rekon.

2. Indikator keberhasilan PDPGR (Program Daerah Pemberdayaan Gotong Royong ) sebagai inovasi penanganan percepatan rehabilitasi dan rekonstruksi pasca gempa di kabupaten Sumbawa Barat dapat ditinjau dari waktu pengerjaan yang relatif lebih cepat daripada target yang diberikan dan kuantitas pngerjaan yang menyeluruh karena proses pendataan yang baik oleh POKMAS Plus. Indikator pendukung lainnya berupa penggunaan dana yang efektif dan efisien serta tidak terdapatnya protes dari masyarakat.

Indikator ini telah disampaikan oleh para Informan baik pejabat formal di Pemda KSB maupun tokoh informal yaitu tokoh agama, tokoh adat, dan tokoh masyarakat.

\section{REFERENSI}

Buku, Desertasi, dan Jurnal

Abdulkadir. 2017. Evaluasi Implementasi PDPGR di Daerah Otonom Baru (DOB) di Kabupaten Sumbawa Barat. Desertasi Universitas Negeri Jakarta

Adisasmita, Rahardjo. 2011. Manajemen Pemerintahan Daerah. Yogyakarta : Graha Ilmu

Effendi, Noer Tadjuddin. 2013. Budaya Gotong Royong Masyarakat dalam Perubahan Sosial Saat ini. Jurnal Pemikiran Sosiologi Volume 2 No.1, Mei 2013
Maleong, Lexy J. 2017. Metode Penelitian

Kualitatif. Bandung : PT. Remaja Rosdakarya.

Pangabean, Mangasi. 2015. Pemberdayaan Masyarakat Dalam Pembangunan. Jurnal Ilmiah "DUNIA ILMU" Vol.1 No.1 Januari 2015

Sudrajat, M Subana. 2005. Dasar- dasar Penelitian Ilmiah. Bandung: Pustaka setia.

Sugiyono. 2013. Metode Penelitian Pendidikan Pendekatan Kuantitatif, Kualitatif, dan $R \& D$. Bandung: Alfabeta

Dr Jalaludin Rakhmat, 30 januari 2012, Kompasiana.com, Rekayasa Sosial.

Nancy Brandon Tuma, 4 April 2018, Sosiologis.com, Dinamika Sosial, di dalam articlenya MacMillan Encyclopedia of Sociology

\section{Peraturan Perundang-undangan}

Peraturan Pemerintah Nomor 21 Tahun 2008 tentang Penyelenggaraan Penanggulangan Bencana Nomor 22 Tahun 2008 tentang Pendanaan dan Pengelolaan Bencana Nomor 23 tentang Peran serta Lembaga Internasional dan Lembaga Asing Nonpemerintah dalam Penanggulangan Bencana

Peraturan Daerah Kabupaten Sumbawa Barat Nomor 3 Tahun 2016 tentang Program Daerah Pemberdayaan Gotong Royong (PDPGR) di Kabupaten Sumbawa Barat

Peraturan Bupati Sumbawa Barat Nomor 19 Tahun 2016 tentang Petunjuk Pelaksanaan Program Daerah Pemberdayaan Gotong Royong di Kabupaten Sumbawa Barat

Peraturan Kepala BNPB Nomor 11 Tahun 2008 tentang Pedoman Rehabilitasi dan Rekonstruksi Pasca Bencana Nomor 14 Tahun 2104 tentang Petunjuk Teknis Tata Cara Pengajuan dan Dana Bantuan Sosial Pasca Gempa

Undang-Undang Nomor 24 Tahun 2007 tentang Penanggulangan Bencana

Undang-Undang Nomor 10 Tahun 2010 tentang Anggaran Pendapatan dan Belanja Nasional (APBN) 